\title{
Exploring the Root Cause for Chronic Kidney Disease of Unknown Etiology (CKDu) via Analysis of Metal Ion and Counterion Contaminants in Drinking Water: A Study in Sri Lanka
}

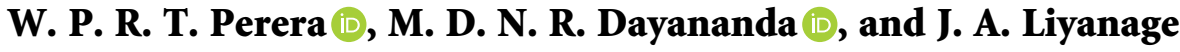 \\ Department of Chemistry, Faculty of Science, University of Kelaniya, Kelaniya 11600, Sri Lanka \\ Correspondence should be addressed to W. P. R. T. Perera; 2017_perera@kln.ac.lk
}

Received 17 July 2020; Revised 5 October 2020; Accepted 7 October 2020; Published 27 October 2020

Academic Editor: Claudio Cameselle

Copyright (c) 2020 W. P. R. T. Perera et al. This is an open access article distributed under the Creative Commons Attribution License, which permits unrestricted use, distribution, and reproduction in any medium, provided the original work is properly cited.

\begin{abstract}
The introduction of elevated amounts of foreign ions into the blood may lead to impairment of the filtration membrane of kidneys and chronic kidney damage. In order to assess the risk of consumption of drinking water (dug well water) in chronic kidney disease of unknown etiology $(\mathrm{CKDu})$, affected areas in Sri Lanka, trace metals, and other counterions in water samples obtained from dug wells were analyzed and compared with a reference area. Drinking water could be the major source that is responsible for entering nephrotoxic ion contaminants into the human body. To achieve the objective, drinking water samples were collected from dug wells in two CKDu endemic areas and a reference area where no CKDu patients were found in a dry season. In the Wewelketiya area (one of the endemic areas), Cd concentrations in $60 \%$ of water samples and $\mathrm{Pb}$ concentrations in $40 \%$ of water samples have exceeded the maximum limit given by Sri Lanka water quality standards. Fluoride concentrations also have exceeded the permissible limits of more than $80 \%$ of collected water samples in both CKDu endemic areas. However, none of the water samples in reference areas has reported that $\mathrm{Cd}, \mathrm{Pb}$, and fluoride are beyond their maximum permissible limits. Hence, people in the particular $\mathrm{CKDu}$ endemic areas are at risk of kidney tissue damage due to long-term exposure to drinking water with elevated levels of some metal ions and counterions.
\end{abstract}

\section{Introduction}

Chronic kidney disease of unknown etiology was first discovered in Sri Lanka in the mid-1990s and was mostly observed among the farmers in the North Central Province (NCP) of Sri Lanka, and since then, over two decades of a period, the disease spread dramatically up to the other farming areas of the country such as Northern, Northwestern, Eastern, Uva, and Central Provinces [1]. Chronic kidney disease (CKD) is a noncommunicable disease that is related to risk factors such as diabetes or hypertension, past snakebites, and urinary tract infections [2-4]. Another study has defined "chronic kidney disease" as either kidney damage or decreased kidney function (decreased GFR) for three months or more [5]. Chronic kidney disease (CKD) is a global public health concern, which is attracting increased global attention because of the disease's rapid spread. However, CKD of unknown etiology CKDu is also prevalent and is progressing rapidly in certain regions of the world, especially in Africa, Central America, and Asia [6].

The occurrence of $\mathrm{CKDu}$ within the same country will vary with the geographic area. An intimate relationship between water quality and the underlying geology has been recorded repeatedly in various geographical regions of the world. Since the CKDu exists in communities where groundwater is the primary source of drinking water, many risk factors are hypothesized, for example, unidentified environmental toxins leading to $\mathrm{CKDu}$ [7], chronic pesticide exposure and enhanced level of heavy metals in water and soil [8], high fluoride levels and potential impacts of AlFx in soil and water [9], and growth of cyanobacteria in water resources $[10,11]$. 
CKDu was discovered mostly among males in the North Central Province (NCP) of Sri Lanka including Anuradhapura and Polonnaruwa Districts (Table 1), and lately, it has also been detected among women and children. Male patients are predominantly farmers and/or agricultural laborers, who are over the age of 40 years [12]. The distribution of the disease can be associated with some geographical and socioeconomic factors which have environmental and occupational origins. NCP of Sri Lanka is a part of the "dry zone" of Sri Lanka, with a rainfall of $\sim 1750$ to $1000 \mathrm{~mm}$ per annum [13], and some studies have shown that the rainfall map largely overlaps with the region affected by CKDu. Now, the disease has spread to nearby districts including Northwestern, Eastern, and Uva Provinces as well. It is a high burden to the country's economy due to the high cost of treatments and the poor income of people in remote areas. Some cohort studies carried out using descriptive hospital records indicated that patients coming to nephrology clinics in Anuradhapura and Kandy were increasing during the period 2001-2002, and the majority of them were CKDu patients [14].

The causes and risk factors for the development of $\mathrm{CKDu}$ vary widely. As the $\mathrm{CKDu}$ prevails in households where groundwater or well water is the main drinking water source, several risk factors can be hypothesized: (a) chronic exposure to chemical pesticides and fertilizers and thereby increase of heavy metals (e.g., $\mathrm{Cd}, \mathrm{Pb}$, and As) in water and (b) presence of high levels of fluoride and other possible counterions such as phosphates and nitrates [15].

Ion imbalances of blood and the introduction of a high load of foreign ions or molecules into the blood cause impairment of the filtration membrane which can result in protein denaturation. Those protein molecules pass into the urine due to the absence of proper maintenance of pore size in the membrane. The glomerular capillaries progressively damage the filtration membrane with the high osmotic pressure gradients and negatively charged proteoglycans can also be affected by higher concentrations of cations [16-18]. Furthermore, toxins are not filtered out from the blood and accumulated in the body. When the dysfunction of kidneys occurs partially or completely, the normal body performances are altered resulting in some serious health issues with confusing etiology such as chronic kidney disease of unknown etiology (CKDu) [19-21].

The intention of the current study is to assess the drinking water quality by evaluating the levels of toxic metals and selected counterions in dug wells of CKDu endemic areas compared with a reference area (CKDu nonendemic areas) and comment on the risk of consumption of the drinking water in selected areas based on Sri Lankan water quality standards. Besides, the study aims to explore the evidence to the link of consumption of well water and the prevalence of kidney disease in selected $\mathrm{CKDu}$ endemic areas.

\section{Methodology}

2.1. Sample Collection. Based on the information obtained from the Ministry of Health, Sri Lanka, Wewalketiya GramaNiladhari division (GND) and Ambagaswewa GND were selected as CKDu endemic areas for water sampling which are located in Anuradhapura District and Polonnaruwa district, respectively, in North Central Province, Sri Lanka. Buddahangala GND in Ampara district was selected as the reference area for the present study. Sampling points for the drinking water sample collection were selected from shallow drinking water wells (dug wells) located in home gardens of the residents which are the main sources of water consumption in their daily life. Thirty dug wells were selected randomly for the water sampling, and all the sampling sites were located within the same climatic zone (dry zone of Sri Lanka). Sampling locations were recorded in the field using the global positioning system (GPS) (Figure 1). The sampling procedure was carried out within August 2019 (dry season) for all selected study areas. Triplicated 30 drinking water samples were collected from each sampling area into uncontaminated Teflon bottles $(125 \mathrm{ml})$ and preserved by adding conc. nitric acid $(0.10 \mathrm{~mL})$ and stored at $4^{\circ} \mathrm{C}$, and another triplicated 30 drinking water samples were collected into uncontaminated Teflon bottles $(125 \mathrm{ml})$ without acidification and stored at $4^{\circ} \mathrm{C}$.

2.2. Analysis of Water Samples. The concentration of trace elements including cadmium, lead, chromium, arsenic, zinc, copper, sodium, potassium, iron, manganese, cobalt, and nickel was determined using Inductively Coupled Plasma Mass Spectrometry (ICP-MS-7800-Agilent, Germany). Multielement ICP-MS standards (AccuStandard, USA) were used for instrumental calibration. Two calibration series ( $1 \mathrm{ppb}-50 \mathrm{ppb}$ and $10 \mathrm{ppb}$ to $1000 \mathrm{ppb}$ ) were prepared using multielement standard. Acidified water samples (with conc. $\mathrm{HNO}_{3}$ ) were filtered through $0.45 \mu \mathrm{m}$ syringe filters before the insertion to the ICP-MS instrument. Phosphate and nitrate concentration in water samples were measured by Ion Chromatographic method according to the US-EPA standard procedures (Method 9056A). Sodium bicarbonate (CASRN 144-55-8) and sodium carbonate (CASRN-497-19-7) were used as an elution solution, and sulfuric acid (CASRN-7664-93-9) was used as a regeneration solution. ACS Reagent grade $1000 \mathrm{mg} / \mathrm{L}$ stock solutions of nitrate and phosphate were used for the standards for anions prepared for a range of concentrations $(0.1 \mathrm{mg} / \mathrm{L}-10 \mathrm{mg} / \mathrm{L})$. Each standard and collected samples were filtered using 0.22-micrometer nylon filters. Samples were introduced, under the flow rate of $0.7 \mathrm{~mL} / \mathrm{min}$ into the Ion Chromatograph (Metrohm Eco IC). Fluoride concentrations of water samples were measured as on-site measurements using calibrated fluoride meter (Eutech Instrument, $\mathrm{pH}$ 510), and when taking the readings, TISAB (III) buffer was used with water sample in 1:1 ratio in order to stabilize the $\mathrm{pH}$ of the medium. Magnesium and calcium concentrations in water samples were determined using a flame atomic absorption spectrophotometer (GBC 5000). A series of standard metal solutions were prepared $(10 \mathrm{ppm}-500 \mathrm{ppm})$ separately using both $\mathrm{Mg}$ and $\mathrm{Ca}$ metal ion standards (1000 ppm, Bibby Scientific) to obtain the calibration curve, and the concentration of $\mathrm{Mg}$ and $\mathrm{Ca}$ of each water sample was determined. 
TABLE 1: CKDu patients in high-risk areas for chronic kidney disease of unknown etiology (CKDu) in Sri Lanka.

\begin{tabular}{|c|c|c|c|}
\hline District & Risk-AGA divisions & 2014 & 2015 \\
\hline Ampara & Dehiattakandiya, Maha oya & 493 & 468 \\
\hline Anuradhapura & All divisions & 8903 & 8412 \\
\hline Polonnaruwa & All divisions & 3483 & 5018 \\
\hline Badulla & Rideemaliyadda, Mahiyangana & 1010 & 943 \\
\hline Kurunegala & Polpithigama & 561 & 1660 \\
\hline Matale & Wilgamuwa & 803 & 1107 \\
\hline Monaragala & Thanamalwila, Wellawaya, Buttala & 246 & 794 \\
\hline Mullaitivu & Welioya & 333 & 486 \\
\hline Vavuniya & Vavuniya south, Cheddikulam & 163 & 1933 \\
\hline Trincomalee & Padavi siripura, Gomarakadawala & 484 & 426 \\
\hline Hambanthota & Tissamharama, Lunugamvehera & 0 & 205 \\
\hline Total & & 16479 & 21452 \\
\hline
\end{tabular}

Source: Ministry of Health, Nutrition and Indigenous Medicine, Sri Lanka, 2016.

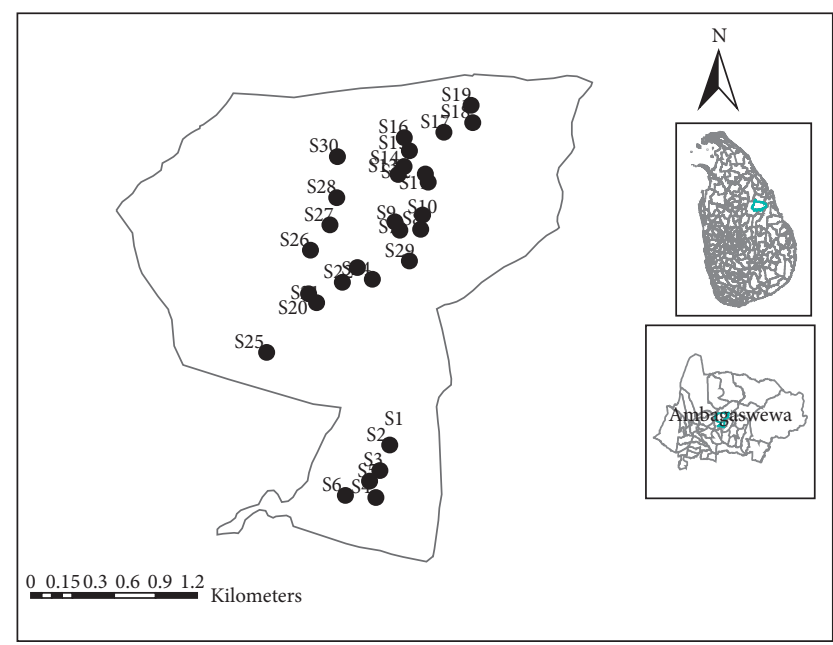

Sampling points

- 0

$\square$ Ambagaswewa GND

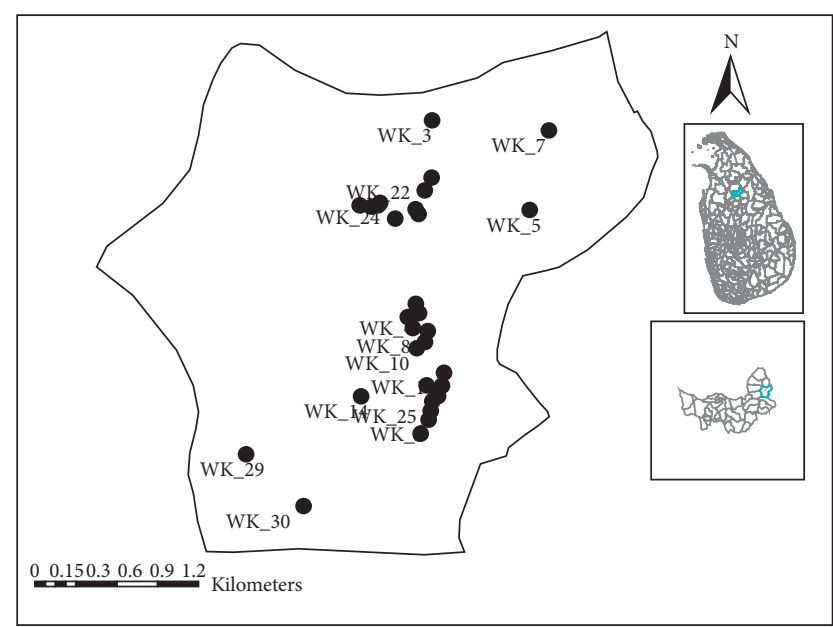

Sampling points

- 0

$\square$ Wewelketiya_GND

(a)

(b)

Figure 1: The distribution of sampling points (Aquifer) which were located in the CKDu prevailed areas: (a) Ambagaswewa GND, Madirigiriya DSD, Polonnaruwa District and (b) Wewalketiya GND, Rambewa DSD, Anuradhapura District, Sri Lanka.

2.3. Geographical Data Treatment and Statistical Data Analysis. ArcGIS 10.2.2 software package was used to perform surface interpolation for all sampling sites using estimated mean values to measure the impact of water contamination in the study area. Statistical analysis was done using SPSS Statistics software. Descriptive statistics were performed on the data sets and a paired $t$-test was carried out to determine the differences or similarities of the chemical parameters recorded in each sampling location.

\section{Results and Discussion}

Chronic renal failure has recently shown a significant increase in some areas in the Anuradhapura and Pollonnaruwa districts. Table 2 summarizes the results of trace metals and some of the counterion concentrations of selected well water samples which are obtained from the Ambagaswewa GND (Madirigiriya DSD in Pollonnaruwa district), Wewalketiya GND, (Rambewa DSD, in Anuradhapura district), and the reference site (Buddhangala GND in Ampara district), respectively, compared with the permissible limits [22]. When considering the causative factors of $\mathrm{CKDu}$, toxic metals are the most important concern including cadmium, chromium, and lead. Cadmium traces naturally occur in phosphate and have been shown to get into water, soil, and also food through fertilizer application. Cadmium is present as an impurity in phosphate fertilizers and refined petroleum products [23]. According to Sri Lanka drinking water quality standards, the maximum permissible level (MPL) of cadmium $(\mathrm{Cd})$ is $3.000 \mu \mathrm{g} / \mathrm{L}$ [22]. In the present study, $60 \%$ of the selected dug wells in Wewalketiya GND in the Anuradhapura district showed elevated Cd levels which exceed 


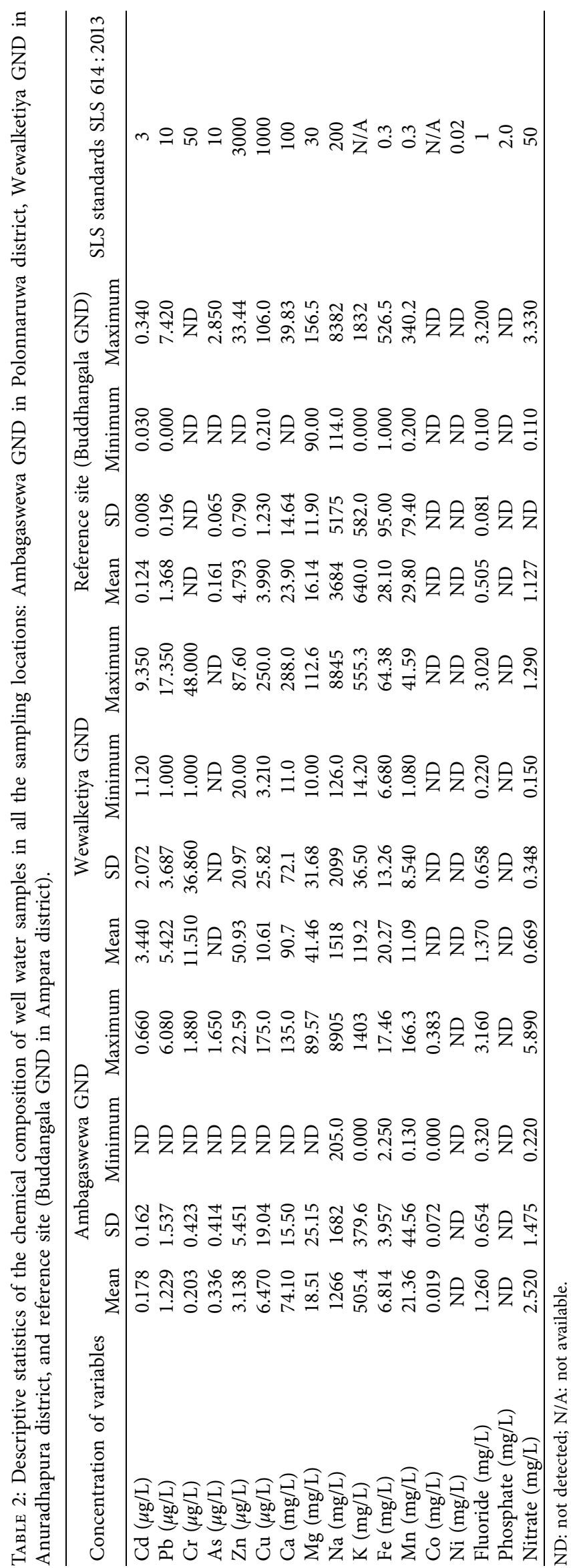


the MPLs. However, drinking water samples obtained from Ambagaswewa GND, Pollonnaruwa district, showed the low levels of $\mathrm{Cd}$ which have not exceeded the MPLs, and also none of the water showed Cd level exceeding the MPLs in the reference area.

However, previously published reports have interpreted that long-term exposure to $\mathrm{Cd}$ via drinking water persists in the kidney and can possibly cause kidney failure through several pathways $[24,25]$, because both renal proximal tubular damage and decline in glomerular filtration rate (GFR) in humans are due to chronic exposure to $\mathrm{Cd}[24,25]$. The cadmium distribution along the sampling sites in particular GNDs is shown in Figure 2 and cadmium concentrations were significantly $(p=0.05)$ higher in Wewalketiya GND with respect to the reference area. But the $\mathrm{Cd}$ concentrations were not significantly different from the reference in Ambagaswewa GND. The increase in geochemical mobility of $\mathrm{Cd}$ can be seen under acidic environmental conditions with the land application of fertilizers and pesticides which increases the total concentration of $\mathrm{Cd}$ in agricultural soils. Acidification of soils and surface waters increases the geochemical mobility of Cd. Cadmium (Cd) has been suggested as a possible factor contributing to the disease, and the source of contamination can be associated with triple superphosphate (TSP) application in paddy and other crop cultivations because TSP use is widespread throughout the agricultural sector in Sri Lanka and especially in the disease prevailed areas [26].

According to the results of the present study, the lead levels in Ambagaswewa GND are reported to be $6.080 \mu \mathrm{g} / \mathrm{L}$ as maximum value with an average of $1.229 \pm 1.537 \mu \mathrm{g} / \mathrm{L}$, and the lead levels in Wewalketiya GND ranged from $1.000 \mu \mathrm{g} / \mathrm{L}$ to $17.350 \mathrm{ppb}$ with the average of $5.422 \pm 3.687 \mu \mathrm{g} / \mathrm{L}$ (Table 2). Even though dug well water samples in Wewalketiya GND showed a huge variation of $\mathrm{Pb}$ concentrations, $40 \%$ of collected samples have exceeded the MPLs of $\mathrm{Pb}$, and in case of renal failure, it was reported that chronic exposure to $\mathrm{Pb}$ can lead to nephrotoxicity characterized by renal effects, such as glomerular sclerosis, interstitial fibrosis, and proximal tubular nephropathy [27] which have been commonly observed among the patients with CKDu in Sri Lanka [23].

Apart from that, ranges of $\mathrm{Cr}$ concentrations of selected dug wells in Ambagaswewa and Wewelketiya areas were reported to be $0.203-0.423 \mu \mathrm{g} / \mathrm{L}$ and $11.5-48.00 \mu \mathrm{g} / \mathrm{L}$, respectively, and all values were below the MPLs. But in the reference area, none of the selected water resources has been contaminated with $\mathrm{Cr}$. In both humans and animals, chromium (III) is found as an essential nutrient that plays a valuable key role in fat, glucose, and protein metabolism, and it is done by the action of insulin [28]. Although chromium (III) has been found as an essential nutrient, both acute and chronic exposure to high levels via inhalation, ingestion, or dermal contact may result in adverse health effects. The kidney is, therefore, one of the main targeting organs for $\mathrm{Cr}$ in acute high doses and chronic cumulative exposure. In addition to that, renal damage and dysfunction caused due to chronic $\mathrm{Cr}$ exposure could involve both the glomerular and tubule [29].
The health effects due to hard water or bicarbonates and sulfates of calcium $(\mathrm{Ca})$ and magnesium $(\mathrm{Mg})$ are significant, and $100 \mathrm{mg} / \mathrm{L}$ [22] for $\mathrm{Ca}$ and $30 \mathrm{mg} / \mathrm{L}$ [22] for $\mathrm{Mg}$ are recommended for drinking water. The results which have been obtained from the sample analysis show variations in $\mathrm{Ca}$ and $\mathrm{Mg}$ concentrations in selected dug wells in Ambagaswewa and Wewelketiya, and most of the samples have reported that $\mathrm{Ca}$ and $\mathrm{Mg}$ concentrations are beyond the MPLs in those CKDu endemic areas. However, in the reference area, the mean concentrations of $\mathrm{Ca}$ and $\mathrm{Mg}$ have been reported to be $23.09( \pm 14.63) \mathrm{mg} / \mathrm{L}$ and $16.14( \pm 11.90)$ $\mathrm{mg} / \mathrm{L}$, respectively, indicating the low values than $\mathrm{CKDu}$ endemic areas. Long-term exposure to the $\mathrm{Ca}$ and $\mathrm{Mg}$ ions via drinking water may adversely affect kidney dysfunctions modifying the risk for calcium stones and increasing the risk of calcium-containing kidney stones [30].

Fluoride can occur naturally in water above desirable levels. Fluoride also has been proposed as a cause of CKDu $[9,31,32]$, and according to Sri Lanka drinking water quality standard, the maximum permissible level (MPL) of fluoride (F) is $1.0 \mathrm{mg} / \mathrm{L} \mathrm{[22].} \mathrm{However,} \mathrm{the} \mathrm{higher} \mathrm{fluoride} \mathrm{levels} \mathrm{in}$ the collected drinking water samples (Figure 3) were recorded in Wewalketiya GND (average: $1.370 \pm 0.658 \mathrm{mg} / \mathrm{L}$ ) and Aambagaswewa GND (average: $1.260 \pm 0.654 \mathrm{mg} / \mathrm{L}$ ) compared to the reference area (average: $0.505 \pm 0.765 \mathrm{mg}$ / $\mathrm{L}$ ), and both CKDu endemic areas have exceeded the MPLs of fluoride in the collected drinking water samples. The variations of fluoride levels in all sampling locations are shown in Figure 3. Furthermore, $80 \%$ of the samples in Ambagaswewa GND and 95\% of samples in Wewalketiya GND were contaminated with fluoride which has exceeded the standard limits [22].

Excessive and long-term exposure to fluoride can be directly related to kidney tissue damage because high fluoride zones for groundwater overlap with CKDu-prevalent regions in NCP [31]. Patients with reduced glomerular filtration rate are having an increased risk of chronic fluoride toxicity because they have less ability to excrete fluoride via urine [33]. According to the dose-effect relationship between fluoride levels and CKDu [34], unexpected effects of fluoride on cellular systems have been investigated by Agalakova and Gusev [35] which clearly reveal that fluoride can affect oxidative stress, intracellular redox homeostasis, lipid peroxidation, protein synthesis inhibition, gene expression alteration, and apoptosis.

A range of geological factors such as dissolution rates and residence times of fluoride-bearing rocks can be related to higher fluoride levels in shallow wells in those areas. The minerals, namely, charnockite, granitic, hornblende, and biotitic gneisses [11, 36], and also fluoride-bearing minerals such as micas, pyroxene, fluorite, tourmaline, topaz, sphene, and apatite can enhance the fluoride levels in soil [37]. Fluoride in the water can be a potential causal factor in the development of the disease because of not only the impacts of fluoride itself but also its interaction with other ionic constituents such as $\mathrm{Ca}, \mathrm{Na}$, and possibly $\mathrm{Mg}$ that are present in the drinking water [11].

In particular, collected water samples were having high ionic content with the presence of high amounts of main 


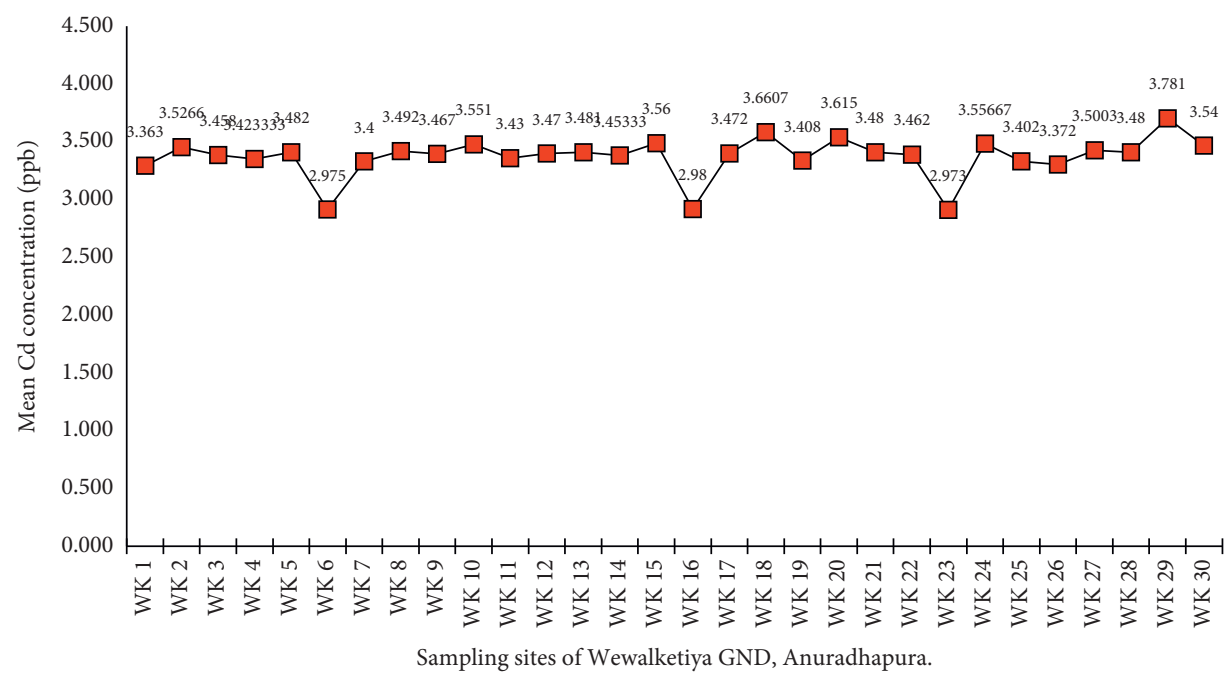

(a)

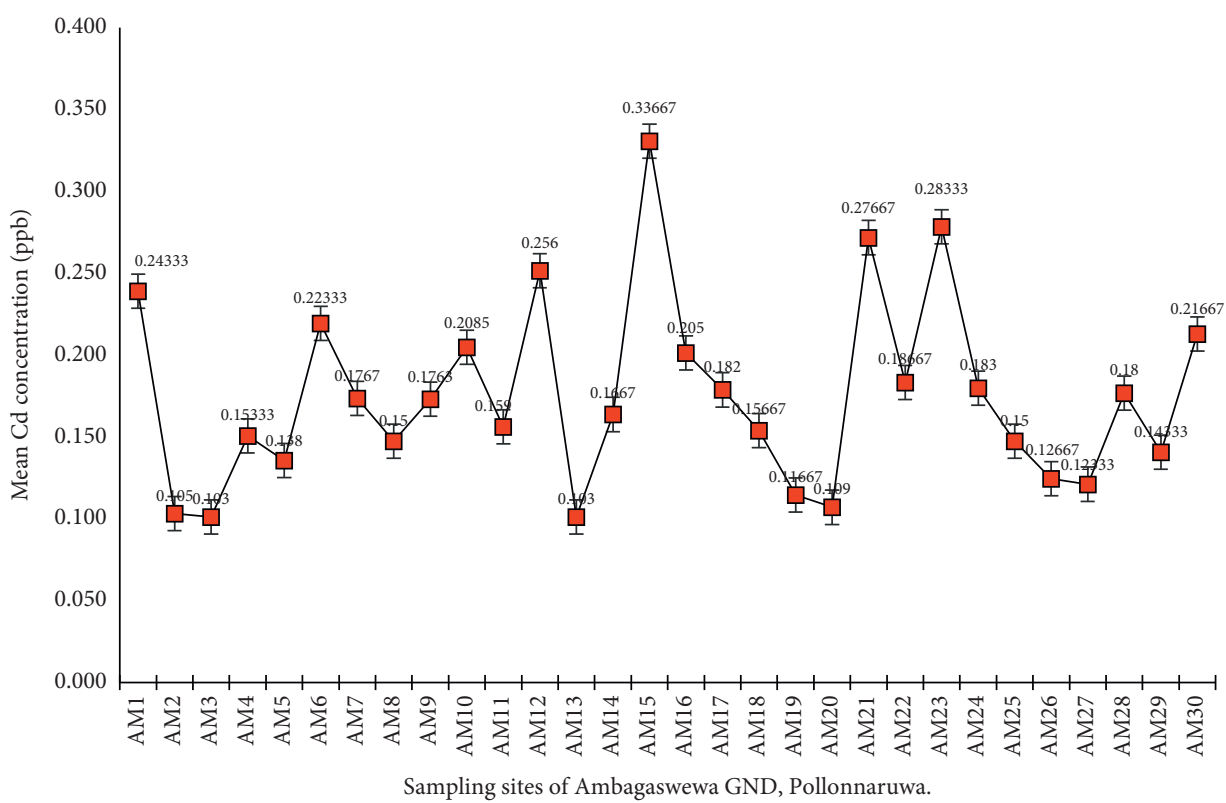

(b)

Figure 2: Continued. 


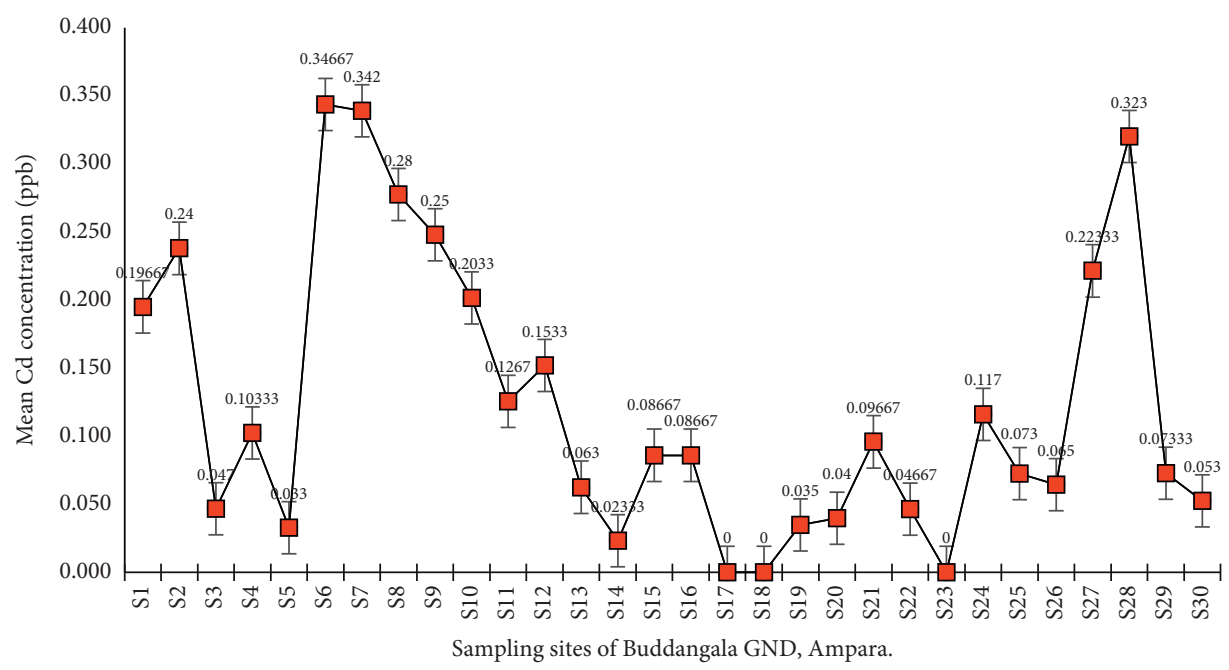

(c)

Figure 2: Cadmium concentrations in drinking water samples collected from (a) sampling sites of Wewelketiya GND, in Anuradhapura district, (b) sampling sites of Ambagaswewa GND, in Polonnaruwa district, and (c) sampling sites of Buddangala GND (Reference) in Ampara district.

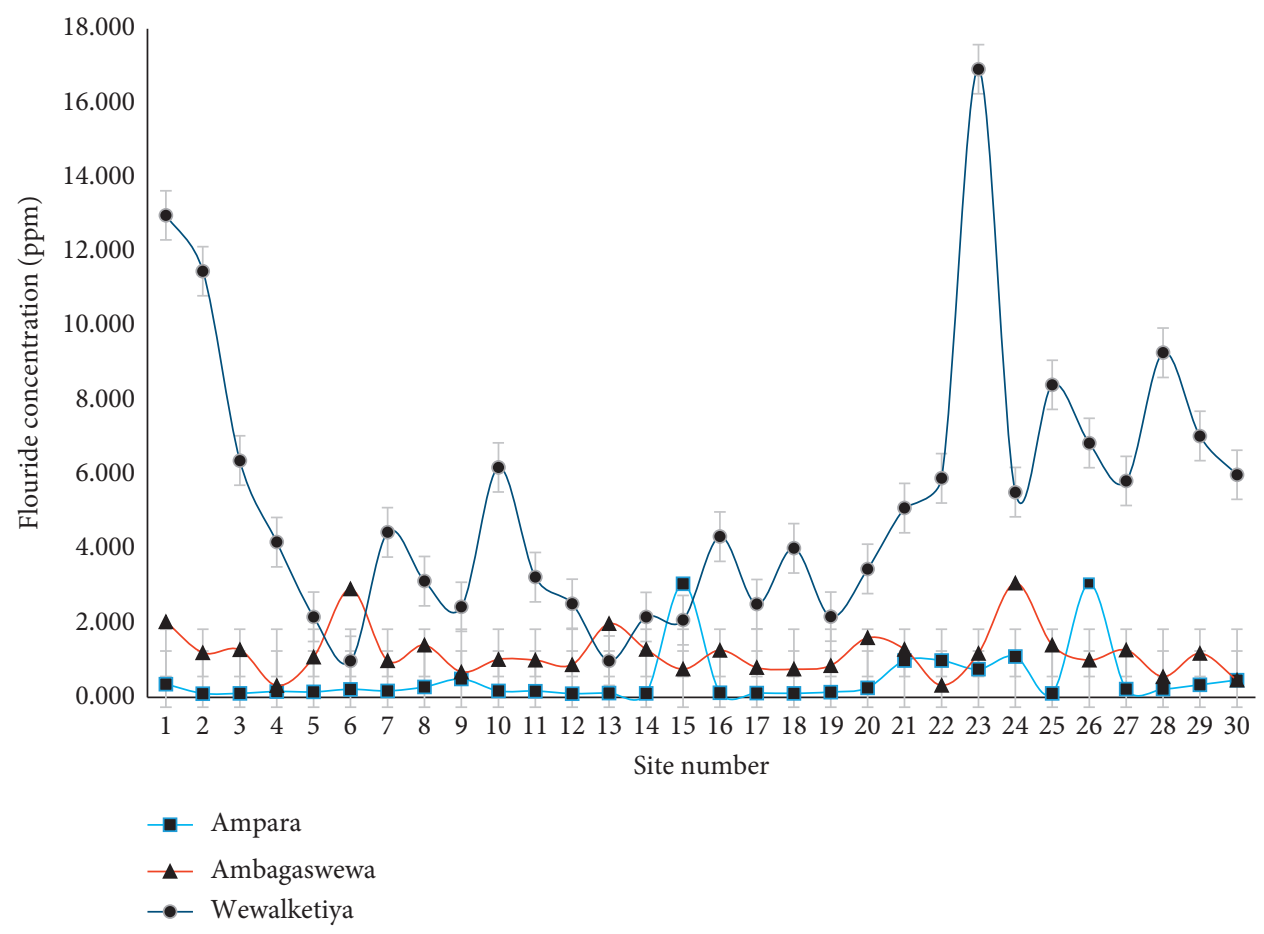

Figure 3: Variations of fluoride concentrations along the sampling points in the reference site (Buddangala) and disease prevalence areas (Ambagaswewa and Wewalketiya).

ions such as $\mathrm{Na}+$ and $\mathrm{K}+$ which are normally found in water. The increased iconicity of drinking water can influence the depletion of water molecules near the kidney membrane, changing water activity and ion activity, osmotic activity, and hydrophobic interactions. When ranking the ions by their capacity to denature proteins, the cations including potassium, sodium, magnesium, and calcium and anions such as fluoride and phosphates play a major role which are present in higher contents in collected drinking water samples from sampling locations [21]. Fertilizer runoff which contains most of those ionic agents can contribute to the pollution of drinking water sources in that area. 
Similarly, some anions such as fluoride and phosphates are the most active in protein denaturation, while nitrates are the least effective. Alteration of the composition and hydrology of the soil may lead to increased ionicity of adjacent water sources. The alternating reducing and oxidizing conditions (depending on the environmental and climate conditions of the areas) of soil promote the addition of iron $(\mathrm{Fe})$ and manganese $(\mathrm{Mn})$ into the soil solution which would get partly leached out into the water table which is indicated by the results of having high $\mathrm{Fe}$ and $\mathrm{Mn}$ contents in all sampling locations (Table 2). Those redox fluctuations of soil may decrease the $\mathrm{pH}$ of the solution due to some nonequilibrium ionic processes such as the conversion of carbonate to bicarbonate and reaction with ambient carbon dioxide $\left(\mathrm{CO}_{2}\right) \cdot \mathrm{pH}$ reduction of the soil solution will lead to the release of soil-bound toxic heavy metals and those are added to the water sources in those areas. Intensive usage of chemical fertilizers and pesticides is also responsible for the reduction of soil $\mathrm{pH}$ levels $[17,21]$.

The kidney needs "good" drinking water [38-40]. It can be considered that the long-term exposure of the kidney to the drinking water that contains many ionic species and has high ionicity, which are going to persist in the kidneys, can adversely affect them. Such exposure is termed "chronic exposure". Chronic exposure is when exposure occurs continuously with toxic substances over a long period of time [38]. Aquifers of those areas are constantly replenished by water with high ionicity from Mahaweli channels as well as frequent oxidation-reduction of those aquifers releasing and increasing quantities of ions to water table [21].

\section{Conclusion}

The persistence of exceeded levels of $\mathrm{Cd}, \mathrm{Pb}$, and fluorides which influence the kidney function in some selected dug wells in CKDu endemic areas indicates a risk of consuming the drinking water from those resources. Even though other analyzed trace elements and counterions in drinking water samples have not exceeded the permissible limits, long-term exposure of the kidney via drinking water with elevated levels of ions augments the occurrence of kidney failure. Contamination of drinking water sources with trace metals and fluoride mainly occurs by the release of ions bound to soil particles from the soil. Hence, it is worth investigating the sources and pathways of contamination of toxic metals and fluoride in the soil and further assessments should be carried out to understand the contribution of fertilizer application and other agricultural activities for those contaminations as well. Additionally, toxic metal concentrations of frequent use of fertilizers commonly used in Sri Lanka need to be evaluated continuously.

\section{Data Availability}

The data used to support the findings of this study are included within the article.

\section{Conflicts of Interest}

The authors declare that they have no known competing financial interests or personal relationships that could have appeared to influence the work reported in this paper.

\section{Acknowledgments}

The authors would like to acknowledge the National Institute of Fundamental Studies (NIFS), Kandy, Sri Lanka, and would like to thank Mrs. Sachini Rathnasekara and Mr. Sudesh Hemal for providing language help, writing assistance, and proofreading the article and Amila T. Kannangara, Amitha Suriyaarachchi, and Erandi Udayasiri for supporting the analysis of water samples. This research was funded by the research project PS/DSP/CKDU/ 06/3.5 titled "Establish a CKDu Information and Research Center at the University of Kelaniya, Sri Lanka."

\section{References}

[1] H. Ranasinghe and M. Ranasinghe, "Status, gaps and way forward in addressing the chronic kidney disease unidentified $(\mathrm{CKDu})$ in Sri Lanka," Journal of Environmental Professionals Sri Lanka, vol. 4, no. 2, p. 58, 2015.

[2] M. a. C. S. Jayasumana, P. a. Paranagama, M. D. Amarasinghe et al., "Possible link of chronic arsenic toxicity with chronic kidney disease of unknown etiology in Sri Lanka," Journal of Natural Sciences Research, vol. 3, no. 1, pp. 2224-3186, 2013.

[3] S. Rajapakse, M. C. Shivanthan, and M. Selvarajah, "Chronic kidney disease of unknown etiology in Sri Lanka," International Journal of Occupational and Environmental Health, vol. 22, no. 3, pp. 259-264, 2016.

[4] E. S. Wijewickrama, N. Gunawardena, S. Jayasinghe, and C. Herath, "CKD of unknown etiology (CKDu) in Sri Lanka: a multilevel clinical case definition for surveillance and epidemiological studies," Kidney International Reports, vol. 4, no. 6, pp. 781-785, 2019.

[5] A. S. Levey, J. Coresh, E. Balk et al., "National kidney foundation practice guidelines for chronic kidney disease: evaluation, classification, and stratification," Annals of Internal Medicine, vol. 139, no. 2, pp. 137-147, 2003.

[6] I. Codreanu, N. Perico, S. K. Sharma, A. Schieppati, and G. Remuzzi, "Prevention programmes of progressive renal disease in developing nations (review article)," Nephrology, vol. 11, no. 4, pp. 321-328, 2006.

[7] K. P. Wanigasuriya, R. J. Peiris-John, and R. Wickremasinghe, "Chronic kidney disease of unknown aetiology in Sri Lanka: is cadmium a likely cause?" BMC Nephrology, vol. 12, no. 1, p. 32, 2011.

[8] J. M. R. S. Bandara, H. V. P. Wijewardena, J. Liyanege, M. A. Upul, and J. M. U. A. Bandara, "Chronic renal failure in Sri Lanka caused by elevated dietary cadmium: trojan horse of the green revolution," Toxicology Letters, vol. 198, no. 1, pp. 33-39, 2010.

[9] O. A. Illeperuma, "Geo-environmental factors associated in the rajarata kidney disease," 2019, http://www.sundaytimes. lk/110731/Plus/plus_11.html.

[10] D. M. Dissanayake, J. M. K. B. Jayasekera, P. Ratnayake, W. Wickramasinghe, and Y. A. Radella, "The short term effect cyano bacterial toxin extracts on mice kidney," in Proceedings of the Peradeniya University Research Sessions, vol. 16, Sri Lanka, Sri Lanka, November 2011. 
[11] C. B. Dissanayake, "The fluoride problem in the ground water of Sri Lanka-environmental management and health," International Journal of Environmental Studies, vol. 38, no. 2-3, pp. 137-155, 1991.

[12] Centre for Science and Environment, Environmental Contamination and its Association with Chronic Kidney Disease of Unknown Aetiology in North Central Region of Sri Lanka, Centre for Science and Environment, New Delhi, India, 2012.

[13] Department of agriculture, Govenmrnt of Sri Lanka, 2019, https://www.doa.gov.lk/index.php/en/2015-09-27-05-42-28/ forms-and-guiedlines.

[14] T. N. C. Aturaliya, D. T. D. J. Abeysekera, P. H. Amerasinghe, P. V. Kumarasiri, and P. Bandara, "Towards understanding of chronic kidney disease of North Central province," in Proceedings of Annual Scientific Sessions of Sri Lanka Medical Association, Balaclava, Australia, March 2006.

[15] S. Y. Lu, H. M. Zhang, S. O. Sojinu, G. H. Liu, J. Q. Zhang, and H. G. Ni, "Trace elements contamination and human health risk assessment in drinking water from Shenzhen, China," Environmental Monitoring and Assessment, vol. 187, p. 4220, 2015.

[16] T. Bertani, F. Cutillo, C. Zoja, M. Broggini, and G. Remuzzi, "Tubulo-interstitial lesions mediate renal damage in adriamycin glomerulopathy," Kidney International, vol. 30, no. 4, pp. 488-496, 1986.

[17] C. J. Burton and J. Walls, "Proximal tubular cell, proteinuria and tubulo-lnterstitial scarring," Nephron, vol. 68, no. 3, pp. 287-293, 1994.

[18] US-EPA, "National management measures to control nonpoint source pollution from agriculture," Technical Report, United States Environmental Protection Agency Office of Water, Washington, DC, USA, 2003.

[19] I. Y. Kuo and B. E. Ehrlich, "Ion channels in renal disease," Chemical Reviews, vol. 112, no. 12, pp. 6353-6372, 2012.

[20] R. P. Scott and S. E. Quaggin, "The cell biology of renal filtration," The Journal of Cell Biology, vol. 209, no. 12, pp. 199-210, 2015.

[21] M. W. C. Dharma-wardana, S. L. Amarasiri, N. Dharmawardene, and C. R. Panabokke, "Chronic kidney disease of unknown aetiology and ground-water ionicity: study based on Sri Lanka," Environmental Geochemistry and Health, vol. 37, no. 2, pp. 221-231, 2014.

[22] SLS-614, "Sri lankan drinking water (portable water) quality standards," 2019, https://www.slsi.lk/images/downloads/ other/accredited_tests_1.pdf.

[23] R. Chandrajith, S. Nanayakkara, K. Itai et al., "Chronic kidney diseases of uncertain etiology (CKDue) in Sri Lanka: geographic distribution and environmental implications," Environmental Geochemistry and Health, vol. 33, no. 3, pp. 267-278, 2011.

[24] L. Harada, L. Hellstro"m, T. Alfve'n et al., "Low level exposure to cadmium and early kidney damage: the OSCAR study," Occupational and Environmental Medicine, vol. 57, no. 10, pp. 668-672, 2000.

[25] S. Thijssen, J. Maringwa, C. Faes, I. Lambrichts, and E. Van Kerkhove, "Chronic exposure of mice to environmentally relevant, low doses of cadmium leads to early renal damage, not predicted by blood or urine cadmium levels," Toxicology, vol. 229, no. 1-2, pp. 145-156, 2007.

[26] N. Lugon-Moulin, L. Ryan, P. Donini, and L. Rossi, "Cadmium content of phosphate fertilizers used for tobacco production," Agronomy for Sustainable Development, vol. 26, pp. 151-155, 2006.
[27] International Programme on Chemical Safety (IPCS), Cadmium, Environmental Health Criteria 134, World Health Organization, Geneva, Switzerland, 1992.

[28] R. A. Anderson, "Nutritional role of chromium," Science of the Total Environment, vol. 17, no. 1, pp. 13-29, 1981.

[29] I. Franchini and A. Mutti, "Selected toxicological aspects of chromium(VI) compounds," Science of the Total Environment, vol. 71, no. 3, pp. 379-387, 1988.

[30] P. Messa, M. Marangella, L. Paganin et al., "Different dietary calcium intake and relative supersaturation of calcium oxalate in the urine of patients forming renal stones," Clinical Science, vol. 93, no. 3, pp. 257-263, 1997.

[31] O. A. Illeperuma, H. A. Dharmagunawardhane, and K. R. P. Herath, "Dissolution of aluminium from substandard utensils under high fluoride stress: a possible risk factor for chronic renal failures in the North-Central province," Journal of the National Science Foundation of Sri Lanka, vol. 37, no. 3, pp. 219-222, 2009.

[32] K. M. S. B. Kulatunga and O. A. Illeperuma, "Fluoride assisted aluminium leaching during cooking and its relevance to chronic renal failure," in Proceedings of the International Symposium, Water Quality And Human Health, vol. 1, p. 53, Peradeniya, Sri Lanka, March 2013.

[33] H. Schiffl, "Fluoridation of drinking water and chronic kidney disease: absence of evidence is not evidence of absence," Nephrol Dial Transplant, vol. 23, no. 1, p. 411, 2018.

[34] O. Lantz, M.-H. Jouvin, M.-C. De Vernejoul, and P. Druet, "Fluoride-induced chronic renal failure," American Journal of Kidney Diseases, vol. 10, no. 2, pp. 136-13910, 1987.

[35] N. I. Agalakova and G. P. Gusev, "Molecular mechanisms of cytotoxicity and apoptosis induced by inorganic fluoride," ISRN Cell Biology, vol. 2012, Article ID 403835, 16 pages, 2012.

[36] K. R. P. K. Herath, O. A. Ileperuma, H. A. Dharmagunawardhane et al., Environmental Health Risk Factors for the Chronic Renal Failure in Sri Lanka 31st Congress on Science and Technology of Thailand, pp. 18-20, Suranaree University of Technology, Ratchasima, Thailand, 2005.

[37] S. M. Young, A. Pitawala, and H. Ishiga, "Factors controlling fluoride contents of groundwater in north-central and northwestern Sri Lanka," Environmental Earth Sciences, vol. 63, no. 6, pp. 1333-1342, 2011.

[38] T. Thompson, J. Fawell, S. Kunikane et al., "Chemical safety of drinking water: assessing priorities for risk management," Technical Report, WHO, Geneva, Switzerland, 2007.

[39] CEA-SL, Technical report, CEA-SL, Central Environmental Authority, Sri Lanka,http://www.eco-web.com/reg/02553. html June 2019.

[40] US-EPA, “Technical report," US Environmental Protection Agency, Washington, DC, USA, 2019.

[41] "Annual average rainfall of Sri Lanka," 2019, http://www. agrimin.gov.lk/web/images/docs/1266917766m7.pdf.

[42] "Determination of inorganic anions in drinking water by Ion Chromatography (US-EPA Method-9056A)," 2019, https:// www.epa.gov/sites/production/files/2015-12/documents/9056a. pdf.

[43] S. Nanayakkara, T. Komiya, N. Ratnatunga et al., “Tubulointerstitial damage as the major pathological lesion in endemic chronic kidney disease among farmers in North Central Province of Sri Lanka," Environmental Health and Preventive Medicine, vol. 17, no. 3, pp. 213-221, 2012.

[44] Report of Annual Health Statistics, Ministry of Health, Nutrition and Indigenous Medicine (2016), 2019, http://www.health.gov.lk/ moh_final/english/public/elfinder/files/publications/AHB/2017/ AHB_2016.pdf. 